\title{
Customer-driven Operations of the Alumni Association Office in a University
}

\author{
Mauro Allan P. Amparado * \\ Jasmin F. Hinoguin $* *$ \\ mapamparado@gmail.com \\ University of Cebu Lapu-Lapu and Mandaue, \\ Mandaue City, Cebu, Philippines
}

* Director, UCLM Alumni Association

** President, UCLM Alumni Association

\section{Abstract}

This study measured the customer-driven operations systems of the alumni association office in a university through a customer satisfaction survey and narratives of satisfaction and dissatisfaction. This descriptive study was conducted in the alumni association office of a university covering 2016, 2017 and 2018 secondary data. The secondary data from 600 respondents (200 respondents per year) includes quantitative data and narratives from the comments section of the survey instrument. Statistical treatment includes weighted mean and frequencies.

In 2016, the customers perceived the operations as very good. The respondents rated the cleanliness and orderliness of the office as excellent. The rest of the indicators were rated very good. The waiting and processing time for the release of the ID was rated the lowest among ten indicators.

It was noted by the researchers that the respondents viewed the association as excellent in 2017 and 2018. In 2017, four indicators were rated as excellent: cleanliness and orderliness of 
the office, attitude of the office staff, quality of alumni ID released to graduates, and comfort \& personalized service in the office. Moreover, the indicator with the lowest mean was the appearance and content of the association's Facebook Page $®$.

In 2018, eight out of ten indicators were evaluated as excellent. The top three indicators were: attitude of the staff; cleanliness and orderliness of the office; and quality of alumni ID released to graduates. The indicator with the lowest mean was the waiting \& processing time for the release of alumni ID.

Keywords: Customer-driven operations; Attitude of the staff; cleanliness and orderliness; quality of alumni ID; waiting time

\section{Introduction}

Organizations - profit and non-profit - exist to meet the needs of customers. Customers are important to organizations. Without customers, there's no one to absorb the organizations outputs. But it is not enough for managers to simply recognize that customers exist. The revenues earned from customers whose needs are thoroughly and completely satisfied are the lifeblood of any organization. However, it's only through complete and total satisfaction of their needs that customers keep coming back. This type of customer loyalty can reap big rewards for organizations. In fact, one estimate is that "raising customer retention rates by 5 percentage points increases the value of an average customer by 25 percent to 100 percent. Customer-driven operations system is designed around meeting and exceeding customer's needs. Successful organizations (1) think continuously about who their customers are, (2) maintain close and frequent contact with their customers, (3) determine how to provide products in a way that competitors cannot imitate, and (4) determine how to satisfy 
customers' current, anticipated, and even unanticipated needs. In addition, their operations systems support the people and work processes to meet those needs (Robbins \& Coulter, 2001).

Quality is the degree of excellence on which products or services can be ranked on the basis of selected features or characteristics. It is the customer who determines this ranking, and the customer defines the quality in terms of appearance, performance, availability and flexibility. Product quality determines an organization's reputation (Certo, 2009).

In the 1970 's, Dr. Nariaki Kano of Tokyo Rika University, came up with an interesting and practical model for understanding customer satisfaction known as the Kano Model. The Kano Model is a set of ideas for planning a new product, service or process. It lists all the potential customer needs that the product, service or process should perhaps try to satisfy. The resulting customer satisfaction co-efficient analyzes the product, service or processes criteria which have the greatest influence on the customer's satisfaction. Thus, the two-dimensional model combines two characteristics pertaining to quality namely implementing the product function or degree of implementing the features of a product or service and level of satisfaction of the customer. Combining both the quality parameters, namely the performance and customer satisfaction in a two-dimensional plot facilitates understanding quality in a more sophisticated and holistic manner (Ramasamy, 2012).

\section{Related Studies}

In one research, it presents the findings performed on data from a large bank's retail-banking operations. It Illustrates the relationship of customer satisfaction to customer loyalty, and 
customer loyalty to profitability, using multiple measures of satisfaction, loyalty, and profitability. An estimate of the effects of increased customer satisfaction on profitability (assuming hypothesized causality) suggests that attainable increases in satisfaction could dramatically improve profitability (Hallowell, 1996).

In another study, it synthesizes and builds on the efforts to conceptualize the effects of quality, satisfaction, and value on consumers' behavioral intentions. Specifically, it reports an empirical assessment of a model of service encounters that simultaneously considers the direct effects of these variables on behavioral intentions. The study builds on recent advances in services marketing theory and assesses the relationships between the identified constructs across multiple service industries. Several competing theories are also considered and compared to the research model. A number of notable findings are reported including the empirical verification that service quality, service value, and satisfaction may all be directly related to behavioral intentions when all of these variables are considered collectively. The results further suggest that the indirect effects of the service quality and value constructs enhanced their impact on behavioral intentions (Cronin Jr., Brady \& Hult, 2000).

Sivadas \& Baker-Prewitt (2000) utilized a national random telephone survey of 542 shoppers, examines the relationship between service quality, customer satisfaction, and store loyalty within the retail department store context. They also tested two complementary models that examine this interrelationship. The results indicate that service quality influences relative attitude and satisfaction with department stores. Satisfaction influences relative attitude, repurchase, and recommendation but has no direct effect on store loyalty. Fostering favorable relative attitude 
and getting customers to recommend the product or service holds key to fostering store loyalty. Results also indicate support for Oliver's four-stage cognitive-affective-conative-action model of loyalty.

\section{Objectives}

This study measured the customer-driven operations systems of the alumni association office in a university through a customer satisfaction survey and narratives of satisfaction and dissatisfaction.

\section{Methods}

This descriptive study was conducted in the alumni association office of a university covering 2016, 2017 and 2018 secondary data. The secondary data from 600 respondents (200 respondents per year) includes quantitative data and narratives from the comments section of the survey instrument. Statistical treatment includes weighted mean and sum of ranks. To interpret the results, the following ranges were used:

$\begin{array}{lll}4.20-5.00 & - & \text { Excellent } \\ 3.40-4.19 & - & \text { Very Good } \\ 2.60-3.39 & - & \text { Good } \\ 1.80-2.59 & - & \text { Fair } \\ 1.00-1.79 & - & \text { Poor }\end{array}$

\section{Results and Discussion}

Tables 1,2 and 3 shows the profile of the respondents in terms of department, age and year of graduation for 2016, 2017 and 2018. In 2016, the data shows that the top three departments 
who participated in the survey were the College of Marine Transportation (19\%), College of Business \& Accountancy $(15.5 \%)$, College of Marine Engineering (14\%), and College of Customs Administration (14\%). Most of the respondents were 2024 years old (70\%) and graduates of the year 2016 (83.5\%)

\section{Table 1. Profile of the respondents in $2016(n=200)$}

\begin{tabular}{|l|c|c|}
\hline Department & Frequency & Percentage \\
\hline Business \& Accountancy & 31 & 15.5 \\
\hline Computer Studies & 15 & 7.5 \\
\hline Customs Administration & 28 & 14 \\
\hline Criminology & 11 & 5.5 \\
\hline Engineering & 5 & 2.5 \\
\hline Hospitality Management & 17 & 8.5 \\
\hline Marine Engineering & 28 & 14 \\
\hline Marine Transportation & 38 & 19 \\
\hline Nursing & 9 & 4.5 \\
\hline Teacher Education & 18 & 9 \\
\hline Total & 200 & 100 \\
\hline Age & & \\
\hline $20-24$ & 140 & 70 \\
\hline $25-29$ & 31 & 15.5 \\
\hline $30-34$ & 28 & 14 \\
\hline $35-39$ & 1 & 0.5 \\
\hline Total & 200 & 100 \\
\hline Year of Graduation & & \\
\hline 2005 & 1 & 0.5 \\
\hline 2007 & 1 & 0.5 \\
\hline 2009 & 1 & 0.5 \\
\hline 2010 & 1 & 0.5 \\
\hline 2011 & 5 & 2.5 \\
\hline
\end{tabular}




\begin{tabular}{|c|c|c|}
\hline 2012 & 4 & 2 \\
\hline 2013 & 1 & 0.5 \\
\hline 2014 & 7 & 3.5 \\
\hline 2015 & 12 & 6 \\
\hline 2016 & 167 & 83.5 \\
\hline Total & 200 & 100 \\
\hline
\end{tabular}

In 2017, the top three departments who participated in the survey were the College of Marine Transportation (19.5\%), College of Business \& Accountancy (16\%) and College of Hospitality Management (13\%). Majority of the respondents were 20-24 years old $(80 \%)$ and graduates of the year 2017 (73.5\%).

Similarly, the top three departments who participated in the 2018 survey were the College of Teacher Education (34\%), College of Business \& Accountancy (15\%) and College of Marine Transportation (11.5\%). Most of the respondents were $20-24$ years old $(67.5 \%)$ and graduates of the year 2018 (57.5\%).

Tables 4, 5 and 6 presents the customer-driven operations of the alumni association office for 2016, 2017 and 2018. In 2016, the customers perceived the operations as very good. The respondents rated the cleanliness and orderliness of the office as excellent (4.22). The rest of the indicators were rated very good. The waiting and processing time for the release of the ID (3.76) was rated the lowest among ten indicators.

It was noted by the researchers that the respondents viewed the association as excellent in 2017 and 2018 (means of 4.20 and 4.26, respectively). In 2017, four indicators were rated as excellent: cleanliness and orderliness of the office (4.36), attitude of the office staff (4.34), quality of alumni ID released to graduates (4.30), and comfort \& personalized service in the office (4.24). 
Moreover, the indicator with the lowest mean was the appearance and content of the association's Facebook Page ${ }^{\circledR}$.

In 2018, eight out of ten indicators were evaluated as excellent. The top three indicators were attitude of the staff (4.5); cleanliness and orderliness of the office (4.4), and quality of alumni ID released to graduates (4.37). The indicator with the lowest mean was the waiting \& processing time for the release of alumni ID (4.06).

\section{Table 2. Profile of the respondents in $2017(n=200)$}

\begin{tabular}{|l|c|c|}
\hline Department & Frequency & Percentage \\
\hline Business \& Accountancy & 32 & 16 \\
\hline Computer Studies & 13 & 6.5 \\
\hline Customs Administration & 12 & 6 \\
\hline Criminology & 15 & 7.5 \\
\hline Engineering & 12 & 6 \\
\hline Hospitality Management & 26 & 13 \\
\hline Marine Engineering & 24 & 12 \\
\hline Marine Transportation & 39 & 19.5 \\
\hline Nursing & 4 & 2 \\
\hline Teacher Education & 23 & 11.5 \\
\hline Total & 200 & 100 \\
\hline Age & & \\
\hline $20-24$ & 160 & 80 \\
\hline $25-29$ & 25 & 12.5 \\
\hline $30-34$ & 13 & 6.5 \\
\hline $35-39$ & 2 & 1 \\
\hline Total & 200 & 100 \\
\hline Year of Graduation & & \\
\hline 2004 & 1 & 0.5 \\
\hline
\end{tabular}




\begin{tabular}{|l|c|c|}
\hline 2007 & 1 & 0.5 \\
\hline 2008 & 3 & 1.5 \\
\hline 2010 & 4 & 2 \\
\hline 2011 & 2 & 1 \\
\hline 2012 & 3 & 1.5 \\
\hline 2013 & 3 & 1.5 \\
\hline 2014 & 3 & 1.5 \\
\hline 2015 & 11 & 5.5 \\
\hline 2016 & 22 & 11 \\
\hline 2017 & 147 & 73.5 \\
\hline Total & 200 & 100 \\
\hline
\end{tabular}

Table 3. Profile of the respondents in $2018(n=200)$

\begin{tabular}{|l|c|c|}
\hline Department & Frequency & Percentage \\
\hline Business \& Accountancy & 30 & 15 \\
\hline Computer Studies & 19 & 9.5 \\
\hline Customs Administration & 7 & 3.5 \\
\hline Criminology & 10 & 5 \\
\hline Engineering & 8 & 4 \\
\hline Hospitality Management & 12 & 6 \\
\hline Marine Engineering & 19 & 9.5 \\
\hline Marine Transportation & 23 & 11.5 \\
\hline Nursing & 4 & 2 \\
\hline Teacher Education & 68 & 34 \\
\hline Total & 200 & 100 \\
\hline Age & & \\
\hline $20-24$ & 135 & 67.5 \\
\hline $25-29$ & 38 & 19 \\
\hline $30-34$ & 21 & 10.5 \\
\hline $35-39$ & 4 & 2 \\
\hline $40-44$ & 2 & 1 \\
\hline
\end{tabular}




\begin{tabular}{|l|c|c|}
\hline Total & 200 & 100 \\
\hline Year of Graduation & 2 & 1 \\
\hline 2008 & 2 & 1 \\
\hline 2009 & 3 & 1.5 \\
\hline 2010 & 1 & 0.5 \\
\hline 2011 & 4 & 2 \\
\hline 2012 & 2 & 1 \\
\hline 2013 & 3 & 1.5 \\
\hline 2014 & 10 & 5 \\
\hline 2015 & 22 & 11 \\
\hline 2016 & 36 & 18 \\
\hline 2017 & 115 & 57.5 \\
\hline 2018 & 200 & 100 \\
\hline Total & & \\
\hline
\end{tabular}

\section{Table 4. Customer-driven operations of the office for 2016 $(n=200)$}

\begin{tabular}{|l|c|c|}
\hline Indicators & Mean & Interpretation \\
\hline $\begin{array}{l}\text { 1. Appearance and user- } \\
\text { friendliness of the application } \\
\text { forms. }\end{array}$ & 4.08 & Very Good \\
\hline $\begin{array}{l}\text { 2. Payment procedure at Palawan } \\
\text { Express. }\end{array}$ & 3.86 & Very Good \\
\hline $\begin{array}{l}\text { 3. Comfort and personalized } \\
\text { service in the office. }\end{array}$ & 4.00 & Very Good \\
\hline $\begin{array}{l}\text { 4. Waiting and processing time for } \\
\text { the release of alumni ID. }\end{array}$ & 3.76 & Very Good \\
\hline $\begin{array}{l}\text { 5. Cleanliness and orderliness of } \\
\text { the office. }\end{array}$ & 4.22 & Excellent \\
\hline $\begin{array}{l}\text { 6. Quality of alumni ID released to } \\
\text { graduates. }\end{array}$ & 4.12 & Very Good \\
\hline
\end{tabular}




\begin{tabular}{|l|c|c|}
\hline 7. Attitude of the office staff. & 4.19 & Very Good \\
\hline $\begin{array}{l}\text { 8. Appearance and content of the } \\
\text { UCLMAA website, } \\
\text { www.uclmaa.com }\end{array}$ & 4.02 & Very Good \\
\hline $\begin{array}{l}\text { 9. Appearance and content of the } \\
\text { UCLMAA Facebook page, } \\
\text { www.facebook.com/uclmaa }\end{array}$ & 3.98 & Very Good \\
\hline $\begin{array}{l}\text { 10. Appearance and content of the } \\
\text { UCLMAA Facebook group, } \\
\text { www.facebook.com/groups/uclmaa }\end{array}$ & 4.00 & Very Good \\
\hline Grand Mean & 4.02 & Very Good \\
\hline
\end{tabular}




\section{Table 5. Customer-driven operations of the office for $2017(n=200)$}

\begin{tabular}{|l|c|c|}
\hline Indicators & Mean & Interpretation \\
\hline $\begin{array}{l}\text { 1. Appearance and user- } \\
\text { friendliness of the application } \\
\text { forms. }\end{array}$ & 4.28 & Excellent \\
\hline $\begin{array}{l}\text { 2. Payment procedure at Palawan } \\
\text { Express. }\end{array}$ & 4.10 & Very Good \\
\hline $\begin{array}{l}\text { 3. Comfort and personalized } \\
\text { service in the office. }\end{array}$ & 4.24 & Excellent \\
\hline $\begin{array}{l}\text { 4. Waiting and processing time for } \\
\text { the release of alumni ID. }\end{array}$ & 4.01 & Very Good \\
\hline $\begin{array}{l}\text { 5. Cleanliness and orderliness of } \\
\text { the office. }\end{array}$ & 4.36 & Excellent \\
\hline $\begin{array}{l}\text { 6. Quality of alumni ID released to } \\
\text { graduates. }\end{array}$ & 4.30 & Excellent \\
\hline 7. Attitude of the office staff. & 4.34 & Excellent \\
\hline $\begin{array}{l}\text { 8. Appearance and content of the } \\
\text { UCLMAA website, } \\
\text { www.uclmaa.com }\end{array}$ & 4.14 & Very Good \\
\hline $\begin{array}{l}\text { 9. Appearance and content of the } \\
\text { UCLMAA Facebook page, } \\
\text { www.facebook.com/uclmaa }\end{array}$ & 4.08 & Very Good \\
\hline $\begin{array}{l}\text { 10. Appearance and content of the } \\
\text { UCLMAA Facebook group, } \\
\text { www.facebook.com/groups/uclmaa }\end{array}$ & 4.13 & Very Good \\
\hline Grand Mean & 4.20 & Excellent \\
\hline
\end{tabular}




\section{Table 6. Customer-driven operations of the office for $2018(n=200)$}

\begin{tabular}{|l|c|c|}
\hline Indicators & Mean & Interpretation \\
\hline $\begin{array}{l}\text { 1. Appearance and user- } \\
\text { friendliness of the application } \\
\text { forms. }\end{array}$ & 4.34 & Excellent \\
\hline $\begin{array}{l}\text { 2. Payment procedure at Palawan } \\
\text { Express. }\end{array}$ & 4.13 & Very Good \\
\hline $\begin{array}{l}\text { 3. Comfort and personalized } \\
\text { service in the office. }\end{array}$ & 4.26 & Excellent \\
\hline $\begin{array}{l}\text { 4. Waiting and processing time for } \\
\text { the release of alumni ID. }\end{array}$ & 4.06 & Very Good \\
\hline $\begin{array}{l}\text { 5. Cleanliness and orderliness of } \\
\text { the office. }\end{array}$ & 4.4 & Excellent \\
\hline $\begin{array}{l}\text { 6. Quality of alumni ID released to } \\
\text { graduates. }\end{array}$ & 4.37 & Excellent \\
\hline 7. Attitude of the office staff. & 4.5 & Excellent \\
\hline $\begin{array}{l}\text { 8. Appearance and content of the } \\
\text { UCLMAA website, } \\
\text { www.uclmaa.com }\end{array}$ & 4.2 & Excellent \\
\hline $\begin{array}{l}\text { 9. Appearance and content of the } \\
\text { UCLMAA Facebook page, } \\
\text { www.facebook.com/uclmaa }\end{array}$ & 4.16 & Very Good \\
\hline $\begin{array}{l}\text { 10. Appearance and content of the } \\
\text { UCLMAA Facebook group, } \\
\text { www.facebook.com/groups/uclmaa }\end{array}$ & 4.22 & Excellent \\
\hline Grand Mean & 4.26 & Excellent \\
\hline
\end{tabular}

According to Go \& Go, the results of customer feedback may be used for benchmarking and improves the existing system of the organization. It allows the organization to learn the key attributes of the product and service that are most important to the customer. 
feedback also allows companies to learn key attributes in the product or service design that are most important to customers. It also gives companies a chance to recover in case of service failure. Rewarding employees who did well in customer service reinforces its mission of customer satisfaction, that the company values it customers and thus makes their customers happy. Giving rewards communicates the company's commitment to maintaining happy and affirmed employees (2010).

Table 7 presents the positive and negative comments of the respondents in the last three years. Respondents have written on the survey form that they find the processing of the alumni ID fast, they like the attitude of the staff, and the office is clean and organized.

The survey also reveals that the top negative comments were: releasing time of the ID is 1-2 months; use of Palawan Express $\AA$ as external cashier; and that the alumni ID is not recognized by the guards.

Customer satisfaction depends on a product's perceived performance in delivering value relative to a buyer's expectations. If performance exceeds expectations, the buyer is delighted, certainly, a worthy goal of a company. Smart companies aim to delight customers by promising only what they can deliver, then delivering more than they promise. The aim of successful companies today is total customer satisfaction. Customer delight creates an emotional affinity for a product or service, not just a rational preference, and this creates high customer loyalty. Quality has a direct impact on product and service performance (Ac-ac, 2009). 


\section{Table 7. Positive and negative comments of the respondents, 2016-2018 (multiple response)}

\begin{tabular}{|l|c|}
\hline \multicolumn{1}{|c|}{ Positive comments } & Frequency \\
\hline Processing time to apply for ID was fast & 106 \\
\hline Friendly staff & 40 \\
\hline Clean and organized office & 6 \\
\hline Location of the office & 2 \\
\hline Quality of the ID & 2 \\
\hline Conducted homecomings & 1 \\
\hline Website was informative & 1 \\
\hline \multicolumn{1}{|c|}{ Negative comments } & Frequency \\
\hline Releasing time of ID, 1-2 months & 8 \\
\hline Palawan Express as cashier & 3 \\
\hline Alumni ID not recognized by guards & 3 \\
\hline Should open from 12 noon to 2 pm & 2 \\
\hline Number of office staff & 2 \\
\hline Staff members do not smile & 1 \\
\hline Update the UCLMAA website & 1 \\
\hline Staff members do not greet & 1 \\
\hline $\begin{array}{l}\text { Text message should be sent if ID is } \\
\text { available }\end{array}$ & 1 \\
\hline $\begin{array}{l}\text { Conduct more activities sponsored by } \\
\text { association }\end{array}$ & 1 \\
\hline $\begin{array}{l}\text { Computer with internet for website } \\
\text { browsing }\end{array}$ & \\
\hline Update the Facebook Page & \\
\hline
\end{tabular}

The offering will be successful if it delivers value and satisfaction to the target buyer. The buyer chooses between different offerings based on which she perceives to deliver the most value. Value reflects the sum of the perceived tangible and 
intangible benefits and costs to customers. It's primarily a combination of quality, service and price, called the "customer value triad." Value increases with quality and service and decreases with price, although other factors can also play an important role in our perceptions of value. Value is a central marketing concept. We can think of marketing as the identification, creation, communication, delivery, and monitoring of customer value. Satisfaction reflects a person's judgments of a product's perceived performance (or outcome) in relationship to expectations. If the performance falls short of expectations, the customer is dissatisfied and disappointed. If it matches expectations, the customer is satisfied. If it exceeds them, the customer is delighted (Kotler \& Keller, 2009).

\section{Conclusion}

Based on the findings of the study, the graduates perceived the operations of the association as very good in 2016 and has excellent service in 2017 and 2018.

\section{Literature Cited}

Ac-ac, M. V. (2009). Principles of Marketing. Philippines: Anvil Publishing Inc.

Certo, S. (2009). Modern concepts and skills management. $11^{\text {th }}$ edition. Singapore: Pearson Education Inc.

Cronin Jr, J. J., Brady, M. K., \& Hult, G. T. M. (2000). Assessing the effects of quality, value, and customer satisfaction on consumer behavioral intentions in service environments. Journal of retailing, $76(2), 193-218$. 
Go, J. and Go, C. E. (2010). Fundamentals of Marketing in the Philippine setting: Understanding the critical role of the Marketing mix in the success of a company's products and brands. $2^{\text {nd }}$ edition. Philippines: Josiah and Carolina Go Foundation Inc.

Hallowell, R. (1996) "The relationships of customer satisfaction, customer loyalty, and profitability: an empirical study", International Journal of Service Industry Management, Vol. 7 Issue: 4, pp.27-42, https://doi.org/10.1108/09564239610129931

Kotler, P. \& Keller, K. L. (2009). Marketing Management. $13^{\text {th }}$ edition. Singapore: Pearson Education Inc.

Ramasamy, S. (2012). Total quality management. India: Tata McGraw-Hill International Edition Publishing Company Limited.

Robbins, S. P. \& Coulter, M. (2001). Management $6^{\text {th }}$ Edition. Singapore: Pearson Education Asia Pte. Ltd. 
